\title{
Elastic Properties of Protein Functionalized Nanoporous Polymer Films
}

\author{
Haoyu Wang ${ }^{1}$, Charles T. Black ${ }^{2}$ and Pinar Akcora ${ }^{1}$ \\ ${ }^{1}$ Department of Chemical Engineering and Materials Science \\ Stevens Institute of Technology, 1 Castle Point on Hudson \\ Hoboken, New Jersey 07030, USA \\ ${ }^{2}$ Center for Functional Nanomaterials, Brookhaven National Laboratory \\ Upton, New York 11973, USA
}

\begin{abstract}
Retaining the conformational structure and bioactivity of immobilized proteins is important for biosensor designs and drug delivery systems. Confined environments often lead to changes in conformation and functions of proteins. In this study, lysozyme is chemically tethered into nanopores of polystyrene thin films and sub-micron pores in poly(methyl methacrylate) films are functionalized with streptavidin. Nanoindentation experiments show that stiffness of streptavidin increases with decreasing sub-micron pore sizes. Lysozymes in polystyrene nanopores are found to behave stiffer than the sub-micron pore sizes and still retain their specific bioactivity relative to the proteins on flat surfaces. Our results show that protein functionalized ordered nanoporous polystyrene/poly(methyl methacrylate) films present heterogeneous elasticity and can be used to study interactions between free proteins and designed surfaces.
\end{abstract}

Keywords. nanoporous polystyrene, poly(methyl methacrylate), thin film, lysozyme, stiffness, activity, heterogeneous surface 


\section{INTRODUCTION}

It is known that the non-specific adhesion of proteins and cells on material surfaces leads to undesirable events such as inflammation, implant failure and infection. ${ }^{1,2,3}$ Immobilization of proteins are widely used in drug delivery systems or biosensors where it is essential that proteins retain their structural stability and activity. ${ }^{4,5,6,7,8}$ Immobilization of a bioactive compound often reduces its activity due to native structural changes resulting from various complex polar and non-polar interactions between the protein and the surface, as well as the topography of the particular surface. Polar interactions such as electrostatic and ionic screening effects can be manipulated by $\mathrm{pH}$ or salt concentration which subsequently influence the orientation of adsorbed protein..$^{9,10,11}$ Non-polar interactions include hydrophobic attractions and hydration repulsion and determine the binding rates and conformational changes of the protein. ${ }^{12,13,14}$ Furthermore, surface topography (i.e. roughness and patterning) affects the protein-surface interactions by reducing the contact area between the protein and biological surface..$^{15,16}$

Immobilization strategies can also influence the protein orientation and activity. ${ }^{17,18,19}$ For example, amino groups of enzymes can react with epoxy groups on surfaces. ${ }^{20,21}$ The multiple attachments of the amino acid side chains may lead to random orientation of proteins, either partially or completely degrading their activity. ${ }^{22}$ The site-directed immobilization of proteins is, therefore, desirable. For example, the biotinylated surfaces are widely used for binding streptavidin. ${ }^{23}$ DNA-directed immobilization (DDI) method based on the Watson-Crick pairing of two complementary single-stranded nucleic acids can offer unique site selectivity to the semi-synthetic conjugates of nucleic acids and provide high 
stability. ${ }^{24,25}$ Both biotin-streptavidin binding system and DDI method are commonly used as they lead to uniformly oriented proteins on surfaces and retain the protein structure.

Current studies on protein-material interactions typically involve coating surfaces with either polymeric films or biological molecules. ${ }^{26,27,28}$ Polymer brushes shield the underlying substrate from the bio-interface and allow us to tune the chemical and physical surface properties by changing grafting density and molecular weight of brushes. ${ }^{21,29,30}$ Highly hydrophilic polymers such as poly(ethylene glycol) (PEG) or zwitterionic polymers have shown strong hydration repulsion to proteins..$^{31,32,33,34}$ We have recently reported that randomly grafted poly(methyl methacrylate) (PMMA) and streptavidin surfaces with heterogeneous and patchy morphology limit the non-specific adhesion of proteins to modified surfaces. $^{35}$

Recent works have investigated the molecular and cage confinement effect on proteins. For example, proteins encapsulated inside pores of silica sol-gels or hydrogels have reported their effects of confinement on protein structure and stability. ${ }^{36,37,38,39}$ Previous studies have shown that surface chemistry and geometry of mesoporous silica affect the activity and conformation of confined proteins and kinetics of protein-catalyzed reactions. ${ }^{40,41,42}$ However, studying protein confinement using nanoporous materials suffers from certain inherent disadvantages. These include a relatively broad pore size distribution that forces the reliance upon averaged moduli values, and the inability to manipulate both degree and elasticity of confinement. In this work, we use porous block copolymer templates to confine proteins in uniform pore size, shape and chemistry. Block copolymer templates provide confined volumes formed by polymer domains rather than the hydrophilic or hydrophobic character of 
$-25 \mathrm{~nm}$ in

y $\sim 30 \mathrm{~nm}$ opolymer mesoporous silica. We measure stiffness and activity of proteins inside nanopores with well-defined lateral sizes and shapes (standing cylinder, striped patterns). Measuring the elastic properties of polymer and protein tethered nanopores is novel since most studies investigate the nanotopography of heterogeneous biomaterial surfaces but not their mechanical properties. Here, we report the elastic moduli and morphology of planar and heterogeneous and biocompatible surfaces comprised of nanoscale protein and polymer domains. The regularly sized nanopores in polystyrene thin films, prepared from both cylindrical and striped diblock copolymer morphologies, are used as functionalization sites for proteins (Figure 1). Indentation and imaging by atomic force microscopy (AFM) are used to measure the mechanical properties of proteins within confining pores. Furthermore, we created porous polymer films with larger sub-micron pores using AFM lithography in order to measure protein modulus in less-confined environments. We first present how we functionalize porous thin film templates with proteins, and then discuss surface topographies with their indentation and enzyme activity results.
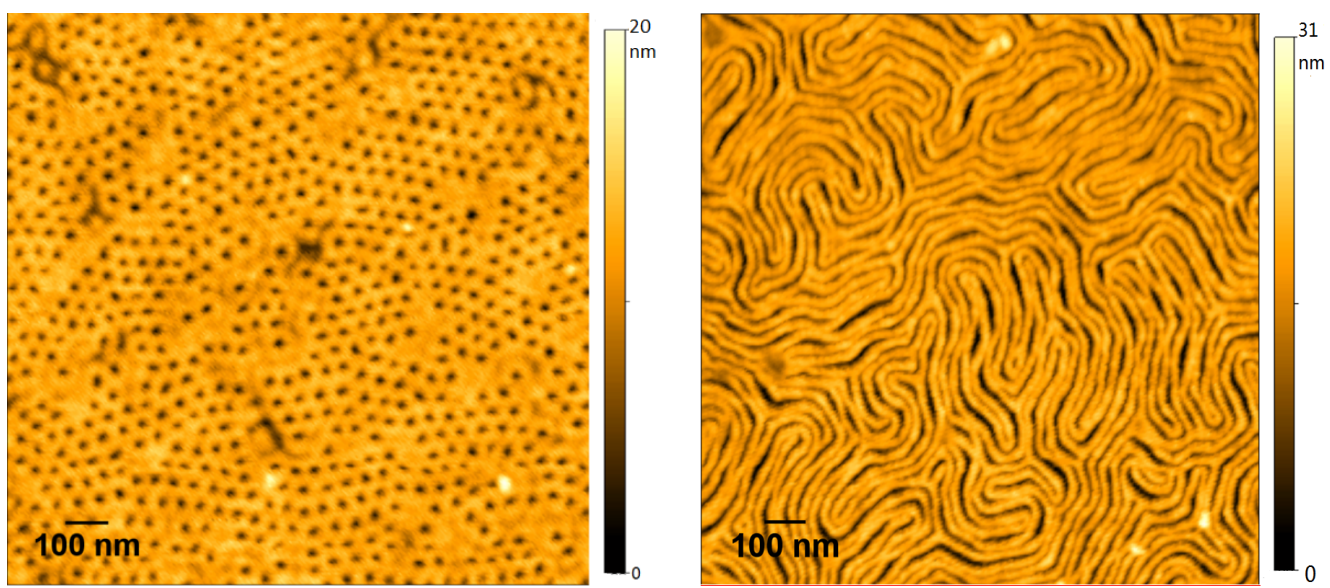


\section{EXPERIMENTAL SECTION}

Materials. Toluene, methanol, ethanol, acetone and sulfuric acid were purchased from PHARMCO-AAPER. 2,2-Dimethoxy-2-phenylacetophenone (DMPA) and triethylamine (TEA) were purchased from Acros Organics. Phosphate Buffered Saline (PBS), streptavidin, lysozyme and EnzChek lysozyme assay kit were purchased from Thermo Scientific. All other chemicals were purchased from Sigma-Aldrich. Methyl methacrylate (MMA) was distilled over $\mathrm{CaH}_{2}$ before use. Silicon wafers with thickness of 356-406 $\mu \mathrm{m}$ were purchased from Silicon Quest International.

Contact angle measurements were performed in a KSV instruments LTD CAM101 system. Fourier Transform Infrared (FTIR) measurements were carried on a Bruker Tensor 27 FTIR spectrometer. Unmodified silicon surface was used as background. All spectra were collected in transmittance mode with a resolution of $4 \mathrm{~cm}^{-1}$ and a total of 800 scans per sample.

Lysozyme activity measurement. The activity of attached lysozyme was measured by following protocols provided by the lysozyme assay kit. A standard curve was generated by running different concentrations of lysozyme solutions ranging from 0-250 U/mL. Lysozyme attached surfaces were equilibrated in PBS for $5 \mathrm{~min}$ in dark prior to incubation in the fluorescent substrate suspension for $3 \mathrm{~h}$ at $37^{\circ} \mathrm{C}$. After extracting solution $(100 \mu \mathrm{L})$ of the fluorescent substrate, activities were measured at Ex495/Em525 with a microplate reader (BioTek) with the use of the standard curve. For each sample, the final result was obtained from the mean value of four measurements.

\section{Preparation of Cylindrical and Striped Nanoporous Block Copolymer Templates}

Self-assembled block copolymer thin films were prepared using polystyrene- $b$-poly(methyl 
methacrylate) (PS- $b$-PMMA) block copolymer purchased from Polymer Source, Inc. Striped morphologies were created with $\bar{M}_{w}=36,000 \mathrm{~g} / \mathrm{mol}$ material with 50:50 PS:PMMA volume ratio, and cylindrical patterns were formed using $\bar{M}_{w}=99,000 \mathrm{~g} / \mathrm{mol}$ with a 70:30 PS:PMMA ratio. First the OH-terminated PS- $r$-PMMA random copolymer was spin-cast from $1 \mathrm{wt} \%$ toluene solution onto the silicon substrate and was thermally annealed at $200{ }^{\circ} \mathrm{C}$ in vacuum for $4 \mathrm{~h}$. Cylindrical and lamellar forming PS- $b$-PMMA block copolymer solution ( $1 \mathrm{wt} \%$ in toluene) was then spin-coated on this pre-treated surface. The underlying random copolymer layer facilitates the perpendicular orientation of microphase-separated PS and PMMA domains, relative to the substrate surface. The resulting films were exposed to UV light (peak wavelengths 185 and $254 \mathrm{~nm}$, at $\sim 10 \mathrm{~mW} / \mathrm{cm}^{2}$ ) for $5 \mathrm{~min}$ and washed with acetic acid for 3 min to remove PMMA blocks. The UV treatment has the simultaneous effect of cross-linking the remaining PS polymer template. Table 1 shows the pore sizes created and used in this work.

Table 1. PS- $b$-PMMA diblock copolymers are used to create nanoporous PS films with cylindrical and striped pore morphology.

\begin{tabular}{cccc}
\hline Sample & Feature type & Pore size (nm) & Spacing (nm) \\
\hline PS-C25 & Cylindrical & 25 & 50 \\
PS-L15 & Striped & 15 & 30 \\
\hline
\end{tabular}

\section{Functionalization of Nanopores with Proteins}

We functionalized the cylindrical and striped nanopores with streptavidin and lysozyme. Standard silanization protocols were followed to attach biotin groups for streptavidin 
functionalization. Silanes with epoxy functional groups within the pores were used to react with the amine functionalities of lysozyme. Specifically, the nanoporous substrate was first immersed into 3-(Trimethoxysilyl)propyl methacrylate (MPS) solution (20 $\mathrm{mM}$ in ethanol), heated at $70{ }^{\circ} \mathrm{C}$ for $7 \mathrm{~h}$, then rinsed with ethanol and dried under nitrogen. Thiolated biotin was prepared by reacting biocytin with an equimolar amount of 2-iminothiolane hydrochloride in 2,2,2-trifluoroethanol (TFE) in the presence of triethylamine (TEA) for $2 \mathrm{~h}$ at room temperature ${ }^{43}$. The substrate was immersed in $5 \mathrm{mM}$ solution of thiolated biotin in TFE with an initiator of 2,2-dimethoxy-2-phenylacetophenone (DMPA) under UV irradiation at $365 \mathrm{~nm}$ wavelength for $10 \mathrm{~min}$. Thiol groups were clicked with alkene groups of MPS using a photoinitiator ${ }^{44}$. Surfaces were then treated with a $100 \mu \mathrm{g} / \mathrm{mL}$ solution of streptavidin in Phosphate Buffered Saline (PBS) for $2 \mathrm{~h}$. The protein attached surfaces were rinsed with $0.05 \mathrm{vol} \%$ solution of Tween 20 in PBS shaken vigorously for $20 \mathrm{~min}$, and immersed in PBS for $5 \mathrm{~h}$ to remove the physically or loosely adsorbed proteins. Finally, the surface was washed in deionized water and dried under nitrogen. Surface functionalization protocol is sketched in Figure 2. Surfaces with lysozyme were prepared similarly by immersing substrates into ethanol solution of (3-Glycidyloxypropyl)trimethoxysilane (GPTMS, $20 \mathrm{mM}$ ) at $70{ }^{\circ} \mathrm{C}$ for 4 $\mathrm{h}$ and soaking in lysozyme solution $\left(50 \mu \mathrm{g} / \mathrm{mL}\right.$ in PBS) at $37{ }^{\circ} \mathrm{C}$ for $3 \mathrm{~h}$. In a control experiment, same protein adsorption and rinsing protocols were applied to unmodified nanoporous substrate to show how proteins are less likely to be physically adsorbed on the nanoporous films. 


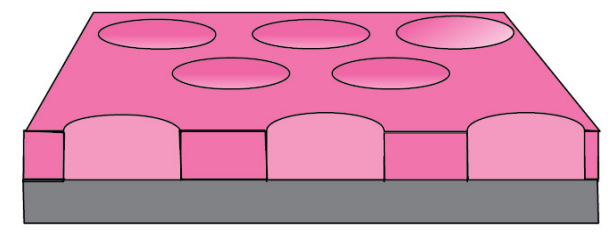

A. Open pores

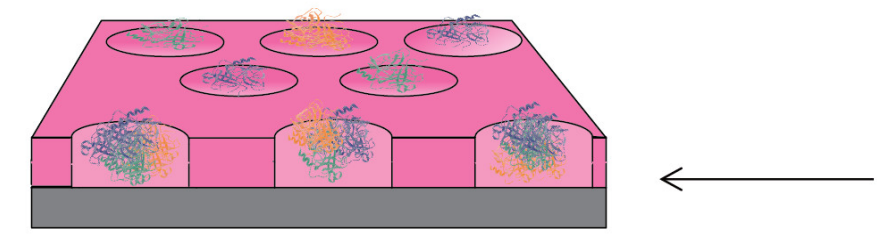

D. Attaching streptavidin

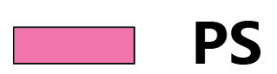

MPS

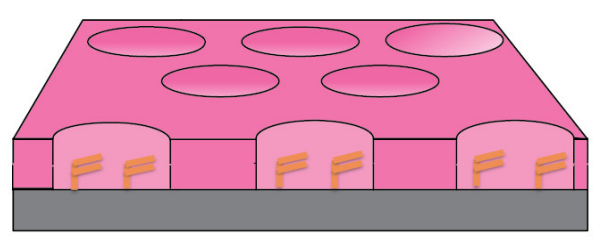

B. Silanization $\downarrow$

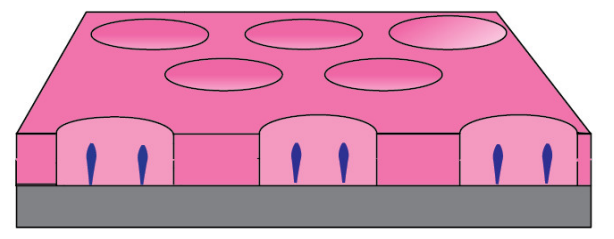

C. Clicking biotin

Biotin

\section{Streptavidin}

Figure 2. Streptavidin functionalization of nanoporous PS films.

\section{Preparation of Surfaces with Sub-Micron Line and Dot Pore Sizes}

Deposition of (3-Mercaptopropyl) trimethoxysilane (MPTMS): Piranha cleaned silicon wafers of $1 \mathrm{x} 1 \mathrm{~cm}^{2}$ were reacted with MPTMS ( $5 \mathrm{mM}$ in toluene) at $70{ }^{\circ} \mathrm{C}$ for $1 \mathrm{~h}$. Surfaces were then rinsed with toluene and dried under nitrogen. AFM lithography was performed using a NANO-I (Pacific Nanotechnology) AFM with a conductive probe (Pt coated, AppNano, Inc.) to remove the MPTMS layer on surfaces. Patterns were created by changing voltage between -2 to $-8 \mathrm{~V}$ (Figure S1). The degraded areas were oxidized into forming hydroxyl groups ${ }^{45}$. The voltage application time was $10-30 \mathrm{~s}$ at scan speed of $0.1-0.5 \mu \mathrm{m} / \mathrm{s}$.

Grafting PMMA onto thiolated surfaces: PMMA $\left(\bar{M}_{n}=22,040 \mathrm{~g} / \mathrm{mol}, Ð=1.07\right)$ was clicked onto thiolated wafers using thiol-ene click reaction. PMMA (100 mg) and photo 
initiator DMPA (5 mg) were dissolved in $2 \mathrm{~mL}$ acetone and solution was spin cast on the MPTMS covered substrates at $2000 \mathrm{rpm}$ for $1 \mathrm{~min}$. Surface was then placed under $365 \mathrm{~nm}$ UV irradiation for $60 \mathrm{~min}$. Finally surface was thoroughly rinsed in toluene and acetone to remove unreacted polymer and DMPA.

Deposition of 3-(trimethoxysilyl) propyl methacrylate (MPS): In this step, MPTMS removed patterns were reacted with MPS in solution (10 mM in toluene) and incubated at $70{ }^{\circ} \mathrm{C}$ for $7 \mathrm{~h}$. MPS modified patterns were then used to functionalize with biotin and streptavidin as described for the nanopores.

\section{RESULTS AND DISCUSSION}

Protein functionalization of surfaces was confirmed by FTIR. Figure 3 shows the amide II $\left(1500-1600 \mathrm{~cm}^{-1}\right)$ and amide I $\left(1650-1700 \mathrm{~cm}^{-1}\right)$ peaks assigned to the lysozyme inside pores. To confirm that these features are not from the non-specifically adsorbed proteins, we prepared surfaces washed with proteins and rinsed with Tween 20, as we do for all of our samples. Figure S2 shows the FTIR transmission data of the protein washed surface and unfunctionalized pores are identical, indicating there is no non-specific adsorption of proteins on our surfaces. Water contact angle of surfaces were measured after each functionalization steps as shown in Figure 2. Figure 4 shows that contact angle increased to $78^{\circ}$ after MPS deposition due to the hydrophobic nature of aliphatic chains in MPS and decreased to $57^{\circ}$ following biotin attachments, because ureido(tetrahydroimidizalone) and tetrahydrothiophene rings of biotin are more hydrophilic than MPS. It is observed that surfaces become more hydrophilic after streptavidin attachment. 


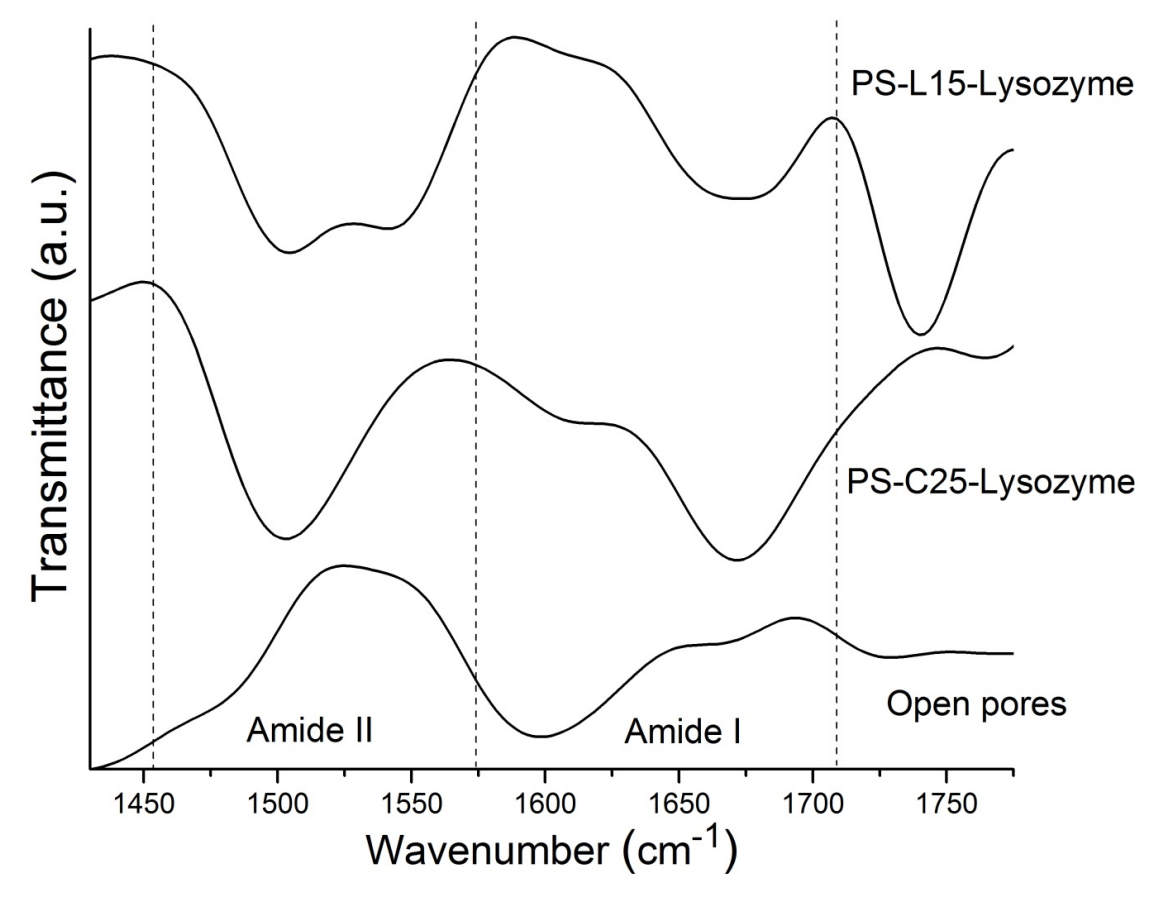

Figure 3. FTIR spectra of PS open nanopores and lysozyme functionalized nanoporous PS films.

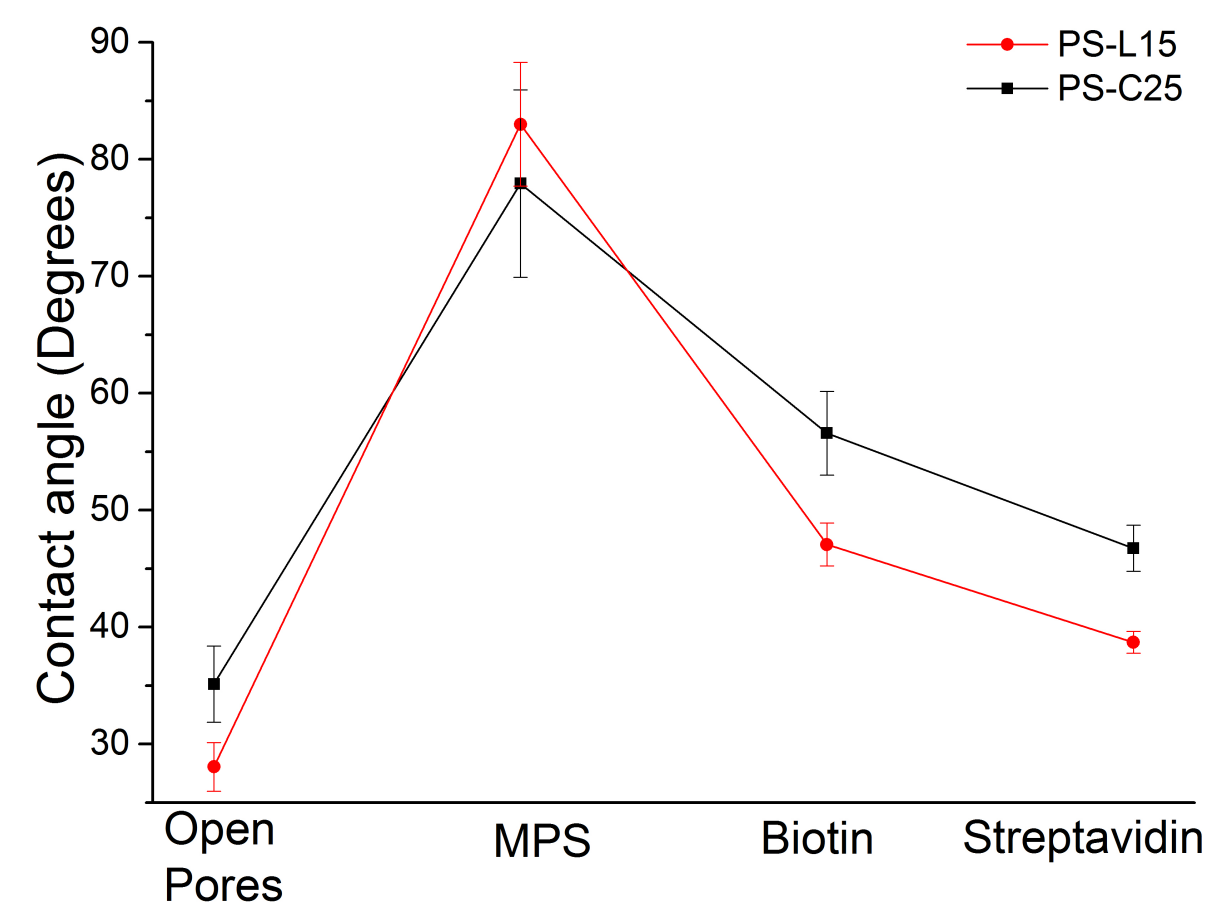

Figure 4. Contact angle measurements on nanopatterned surfaces after MPS, biotin and streptavidin functionalization.

We washed the streptavidin functionalized porous surfaces with DyLight488 fluorophore 
conjugated streptavidin. Fluorescence microscopy image in Figure S3 shows that proteins are not physically adsorbed on the surfaces. This result is important as we conduct nanoindentation experiments on the polymer and protein regions.

\section{Atomic Force Microscopy (AFM) measurements}

AFM imaging and indentation measurements were performed in contact mode with a sharp silicon probe (spring constant $k_{c}=1.6 \mathrm{~N} / \mathrm{m}$, tip radius $R=6 \mathrm{~nm}$, AppNano, Inc.). Images were obtained at a scan rate of $0.6 \mathrm{~Hz}$. Force-distance curves for the Young's modulus calculation were obtained by indenting the tip on selected areas. Different models have been applied in previous indentation studies to determine the elasticity of biological samples in AFM. $^{46,47,48}$ The Hertz model ${ }^{49}$ is primarily used for stiff surfaces but also in biological environments to study the modulus of living mouse fibroblasts ${ }^{50}$, smooth muscle cells ${ }^{51}$ or lysozyme ${ }^{52}$. We note that indentation depths up to $200 \mathrm{~nm}$ are known to be appropriate for the Hertz $^{53}$. The typical indentation depths used on our heterogeneous surfaces were less than 50 $\mathrm{nm}$, indicating that the surfaces are stiff. A rigid unmodified silicon surface was chosen as a reference surface, and the protein modified surface was approximated as a flat, isotropic material with Poisson ratio of 0.4 that was elastically deformed by a spherical AFM tip. 80-120 points of indentation measurements were conducted over the whole surface. The contact area, $A$, between the tip and surface is given by $A=\pi R^{2}$ for axially symmetric tip, where $R$ is the contact radius that is smaller than the tip radius of $6 \mathrm{~nm}^{54}$. Indentation experiments were conducted on a single pore or polymer area in each measurement since nanopores are much larger than the contact radius of the tip. The Young's modulus $\left(E_{t}\right)$ was calculated using the Hertz model: ${ }^{53,55} E_{\mathrm{t}}=3\left(1-v^{2}\right) k_{c} \Delta \mathrm{d} / 4 R^{1 / 2} \mathrm{~h}^{3 / 2}$, where $v$ is the Poisson's 
ratio ( $v=0.4), k_{c}$ is the cantilever spring constant, $\Delta d$ is the cantilever deflection, $R$ is the tip radius and $h$ is the indentation depth. When the tip is indented into a soft sample, the cantilever deflection $(\Delta d)$ and indentation depth $(h)$ were obtained using: $\Delta d=\Delta I / S$, $h=\Delta Z-\Delta d$, where $\Delta I$ is the photodiode current change, $\Delta Z$ is the piezo displacement and the optical sensitivity $(S)$ is calibrated on a clean, unmodified silicon surface. Topographic images of thin films before and after protein attachments are shown in Figure 5. It is measured that depths of open pores are 5-8 $\mathrm{nm}$ and their depths decrease but fluctuate in the protein attached films. This indicates that steptavidin attachment was successful in some of the pores while some remained open both for the cylinder and striped pores.
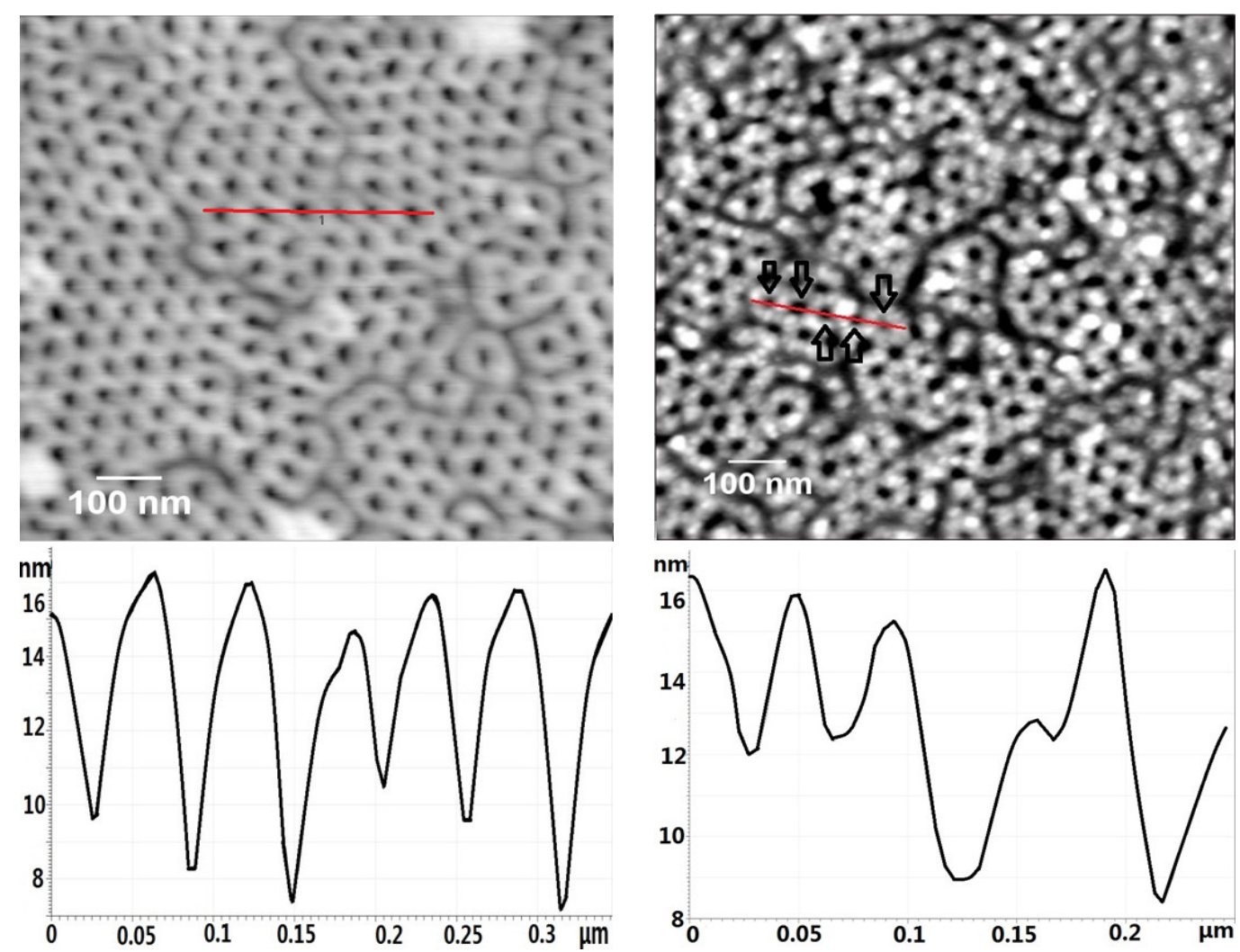

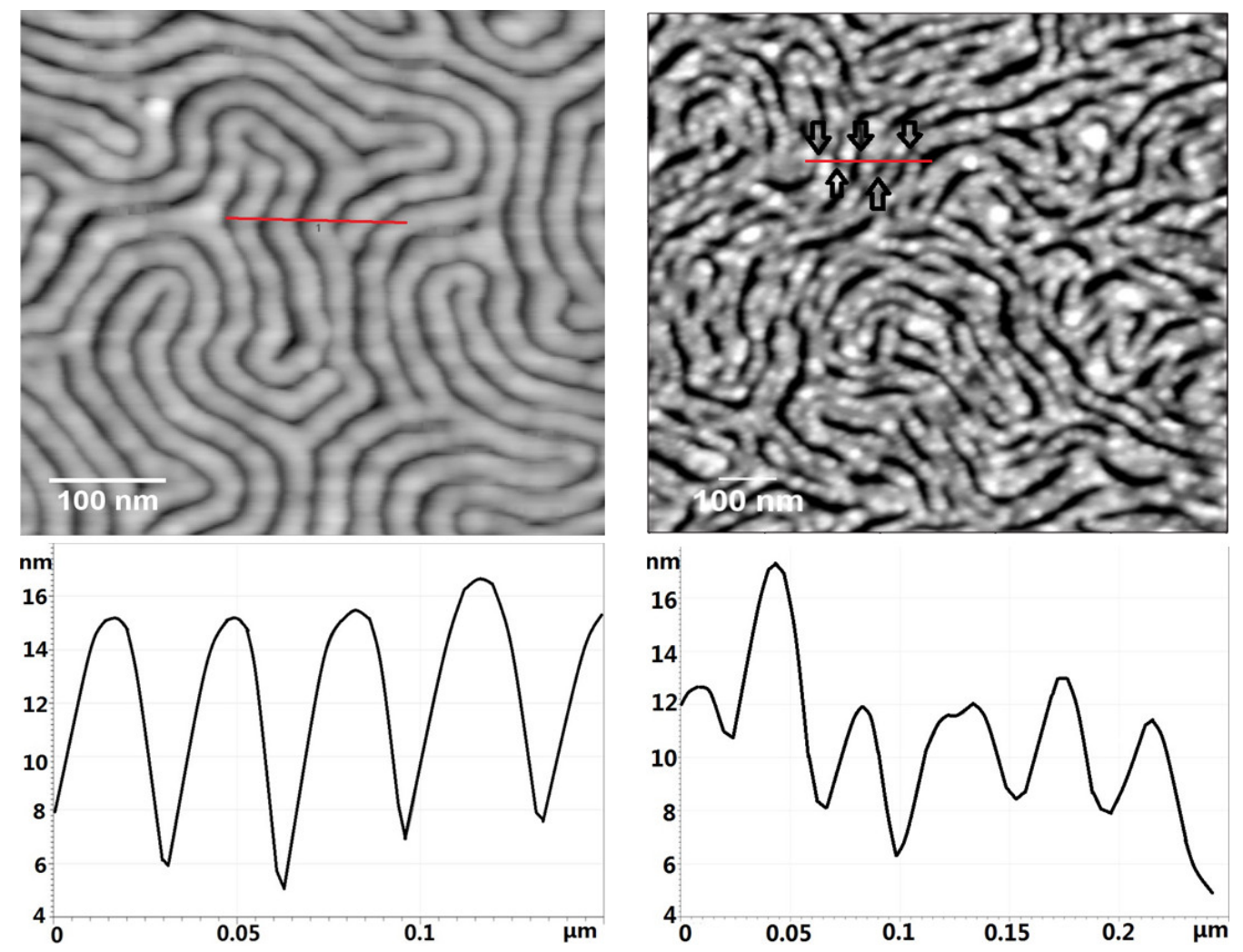

Figure 5. AFM topography images and corresponding pore depth profiles of unfunctionalized surfaces (left), and streptavidin functionalized cylindrical and striped pores (right).

\section{Statistical Nanoindentation Analysis on PS Nanopatterned Surfaces}

Force-distance measurements were conducted along several line scans across the samples at step sizes of $1.5 \mu \mathrm{m}$, with a total of $\sim 150$ measurements in four line scans. Elastic moduli histograms represent the elastic heterogeneity of surfaces (Figure 6). We measured that the modulus for the polymer regions before protein attachments was found to be $\sim 2-5 \mathrm{GPa}$, thus moduli smaller than $2 \mathrm{GPa}$ were attributed to the protein sites. 


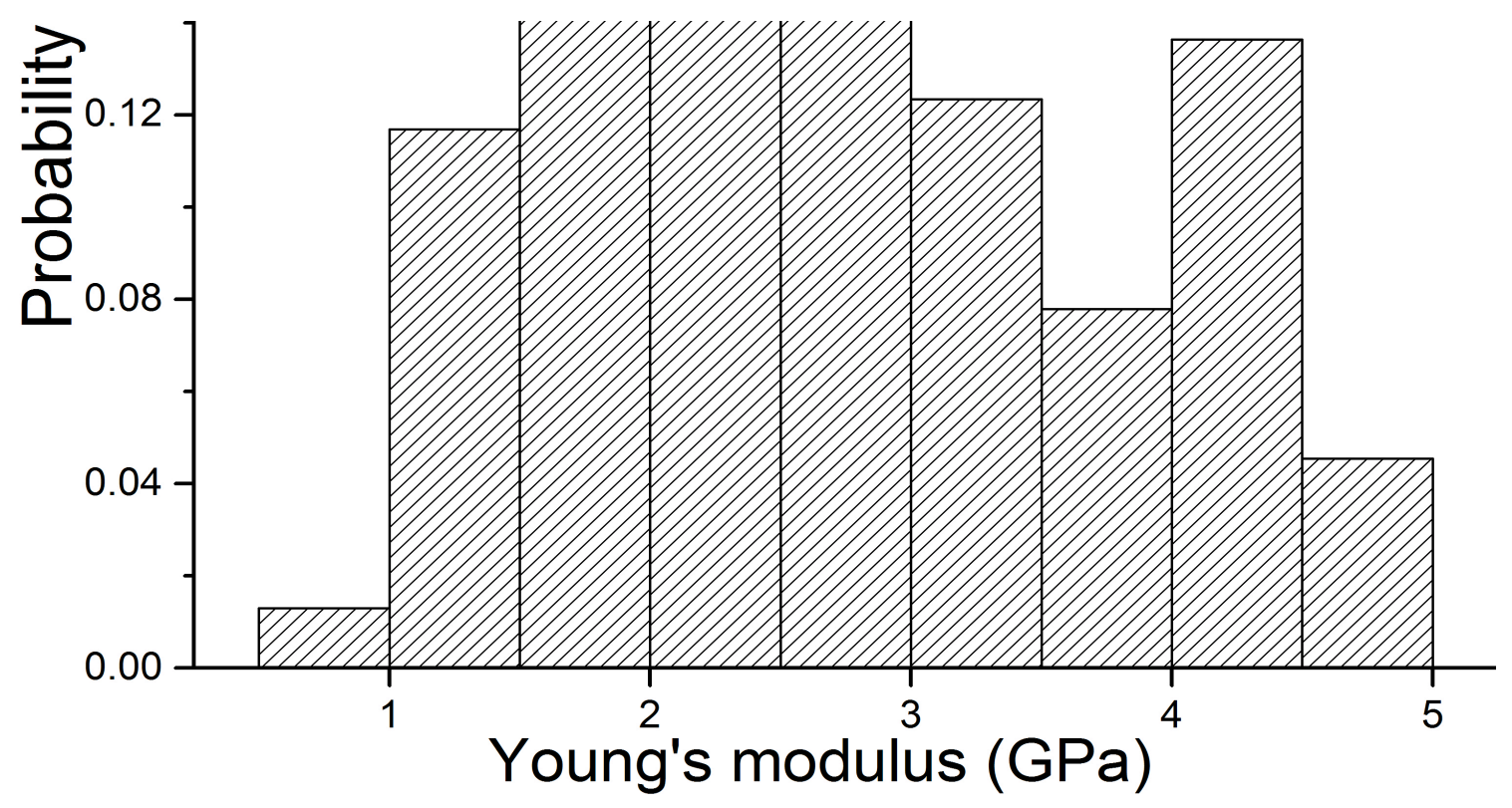

Figure 6. Young's moduli histogram of streptavidin functionalized cylinder pores in PS films.

Figure 7 shows the average moduli of protein sites and polymer regions which are derived from Figure 6. Elastic moduli of streptavidin is $1.35 \mathrm{GPa}$ in cylindrical and $1.94 \mathrm{GPa}$ in striped pores. We also did nanoindentation measurements on selective points using the MFP-3D BioAFM (Asylum Research) located at the Center for Functional Nanomaterials of Brookhaven National Laboratory. After imaging a small area $\left(500 \times 500 \mathrm{~nm}^{2}\right)$ in tapping mode, nanoindentation experiments were conducted in contact mode on the same points. The averaged moduli for streptavidin was found as $1.19 \pm 0.1 \mathrm{GPa}$ in cylindrical and $1.43 \pm 0.2$ GPa in striped pores, which are both close to the values collected by statistical indentation analysis. A similar indentation experiment was performed on lysozyme modified pores and 
the average moduli of attached lysozyme was found to be smaller than that of streptavidin, $0.66 \mathrm{GPa}$ in cylindrical and $1 \mathrm{GPa}$ in striped pores (Figure 8, see Figure S4 for AFM topographies after lysozyme functionalization). We note that polymer stiffness after functionalizing the pores do not change $(\sim 3-3.7 \mathrm{GPa})$, revealing that there is no indication of physical adsorption of proteins on the polymer regions of nanopatterned surfaces, which is also consistent with the fluorescence microscopy images in Figure S3.

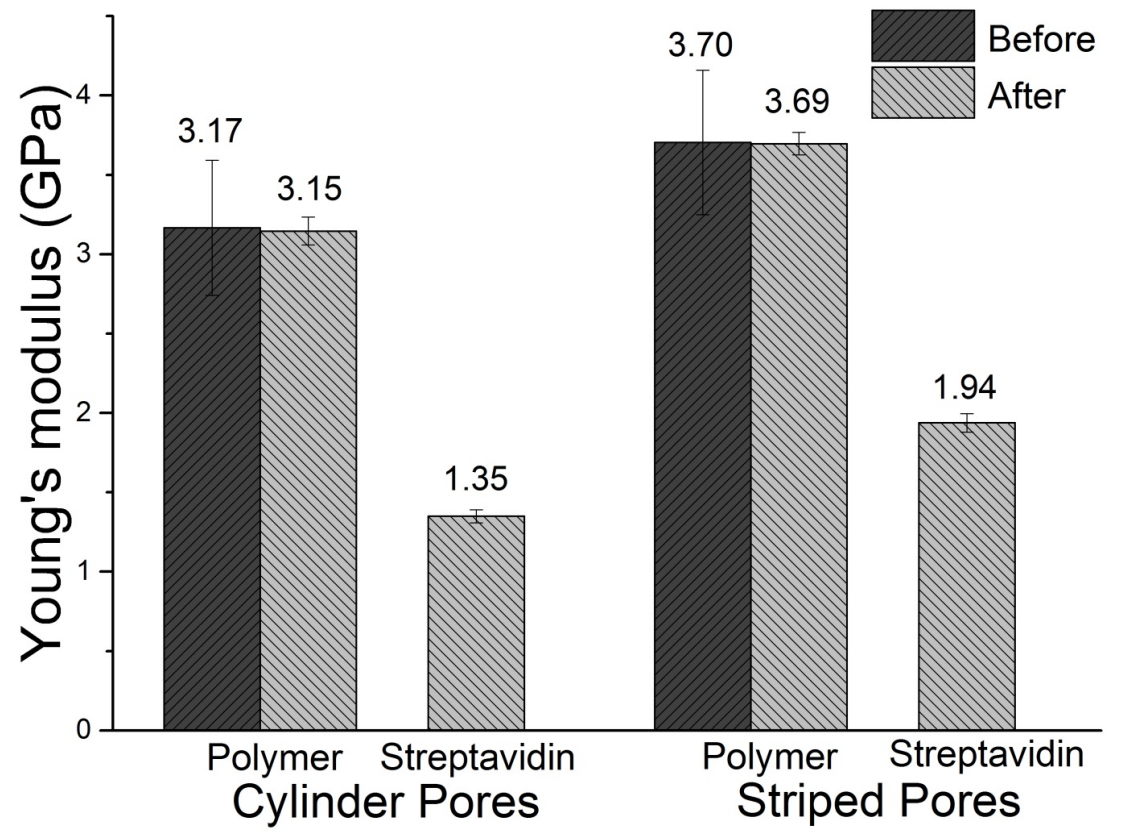

Figure 7. Elastic moduli of PS and streptavidin inside the pores. Modulus of PS is shown before and after protein functionalization.

Activity of an enzyme in biological fluid is of great importance as the formation of hydration layers affects its activity, conformation and elasticity ${ }^{56,57,58}$. We measured the stiffness of lysozyme in PBS solution and compared it with the values measured in dry state (Figure 8). Our results showed that nanopores in solution present lower modulus of lysozyme than measurements on dry films. It is known that the conformational flexibility of protein changes 
its elasticity and biological activity ${ }^{59}$. Thus, the elasticity of proteins in solution is generally connected to the structural changes of proteins in their hydrated forms. We also measured the stiffness of proteins attached to silanized flat surfaces as a reference sample to see whether stiffness by itself is a measure of confinement which could enhance the specific activity. As seen in Figure 8, confined proteins behave less stiff than proteins on the flat surface in dry state. The higher modulus of proteins tethered on flat surfaces may be due to the higher graft density of proteins. The existence of hydrophobic environment inside nanopores can influence the protein binding, and their activity and elasticity. Thus, we concentrate on discussing surfaces with different pore sizes and on their specific activities in PBS solution. We characterized the bioactivity of the immobilized lysozymes within nanopores. Table 2 shows the activity values of lysozyme immobilized within cylinders and stripes. The activities were found to be significantly higher than the previous reported values for lysozymes conjugated on poly(oligo(ethyleneglycol) methacrylate)-b-poly(glycidyl methacrylate) (POEGMA- $b$-PGMA) modified surfaces ${ }^{61}$. Since the covalent binding protocol will lead to a random lysozyme orientation, ${ }^{17,18}$ the total activity loss compared to that of free lysozyme in solution $(100 \mu \mathrm{L})$ is attributed to the conformational structure changes and inaccessibility of lysozyme to functional sites. Our nanoporous surfaces can retain higher activities $\left(\mathrm{U} / \mathrm{cm}^{2}\right)$ compared to lysozyme grafted on silanized silicon surfaces. 


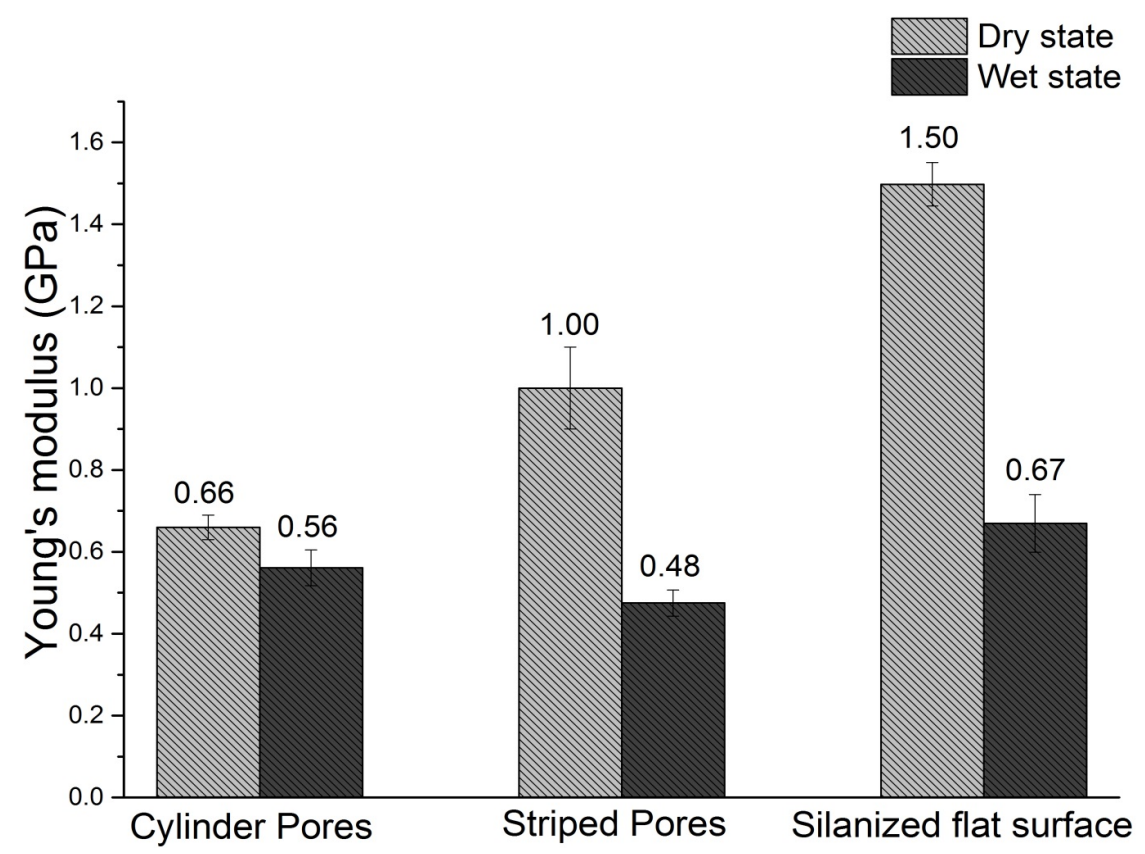

Figure 8. Comparison of elastic moduli of lysozyme inside pores and attached on a flat surface in PBS solution and in dry state.

Table 2. Activity of lysozyme-functionalized nanopores and lysozyme on a flat surface.

\begin{tabular}{c|c|c} 
Sample & Total activity $(\mathbf{U} / \mathbf{m L})$ & Specific activity (U/cm²) \\
\hline PS-C25 (cylindrical) & $15.0 \pm 0.15$ & $5.56 \pm 0.06$ \\
\hline PS-L15 (striped) & $14.5 \pm 0.06$ & $5.43 \pm 0.02$ \\
\hline Silanized flat surface & $28.1 \pm 1.18$ & $3.91 \pm 0.44$ \\
\hline Lysozyme in solution & $207.2 \pm 0.4$ & N/A
\end{tabular}

Non-uniform functionalization of the $15 \mathrm{~nm}$ nanopores, the statistical indentation results and the presented depth profiles have led the preparation of larger pores which provided higher probability for proteins to react with the functional groups. More importantly, the sub-micron pores can be indented directly rather than randomly indenting the points. We have prepared sub-micron size pores using AFM lithography as described in the experimental section. 
PMMA was chosen as the polymer substrate because it is a biocompatible polymer with moderate hydrophobicity and can be degraded easily with applied voltage. We precisely indented the probe into the selected areas of degraded regions in which proteins were chemically tethered. Data from nanoindentation profiles were obtained through the linear region of force-distance curves in AFM. Figure 9 presents the results of indentation measurements on streptavidin functionalized pores; PMMA brushes; and streptavidin washed PMMA brushes. As shown in the graph, physically adsorbed protein on PMMA brush had the highest Young's modulus (1.30 GPa), indicating that adsorbed streptavidin behaves more elastic on PMMA surface. Streptavidin functionalized biotinylated pores had a similar stiffness to that of the pure PMMA brush $(0.76 \mathrm{GPa})$. We found that for very large physically adsorbed protein aggregations with thicknesses larger than $2 \mu \mathrm{m}$ on PMMA surface, the corresponding elastic modulus was measured larger than $3 \mathrm{GPa}$. Since there is no preferential orientation transitions in adsorption of globular-like proteins as observed with anisotropic proteins, ${ }^{60}$ we conjecture that the packing density of protein layer may be a factor for the observed high stiffness. Figure 10 shows that the modulus of streptavidin decreased with increasing pore size. 


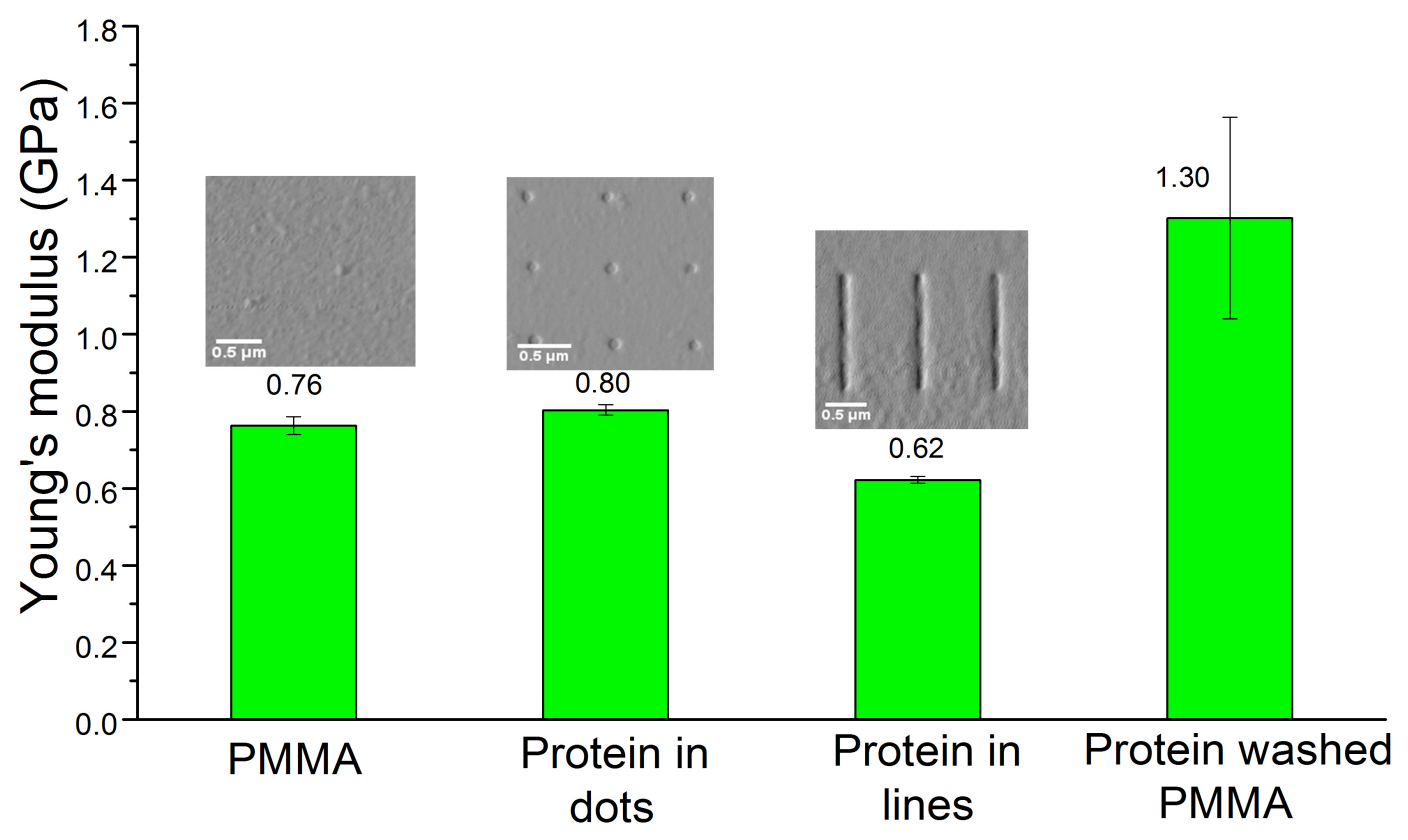

Figure 9. Young's moduli of PMMA brush $(22,000 \mathrm{~g} / \mathrm{mol})$ and streptavidin inside $190 \mathrm{~nm}$ size dots and $124 \mathrm{~nm}$ wide lines, and PMMA brush washed with streptavidin in dry state. The protein washed PMMA coated surface represents the non-specific adsorption of streptavidin on PMMA and the surface was not rinsed with Tween 20 solution.

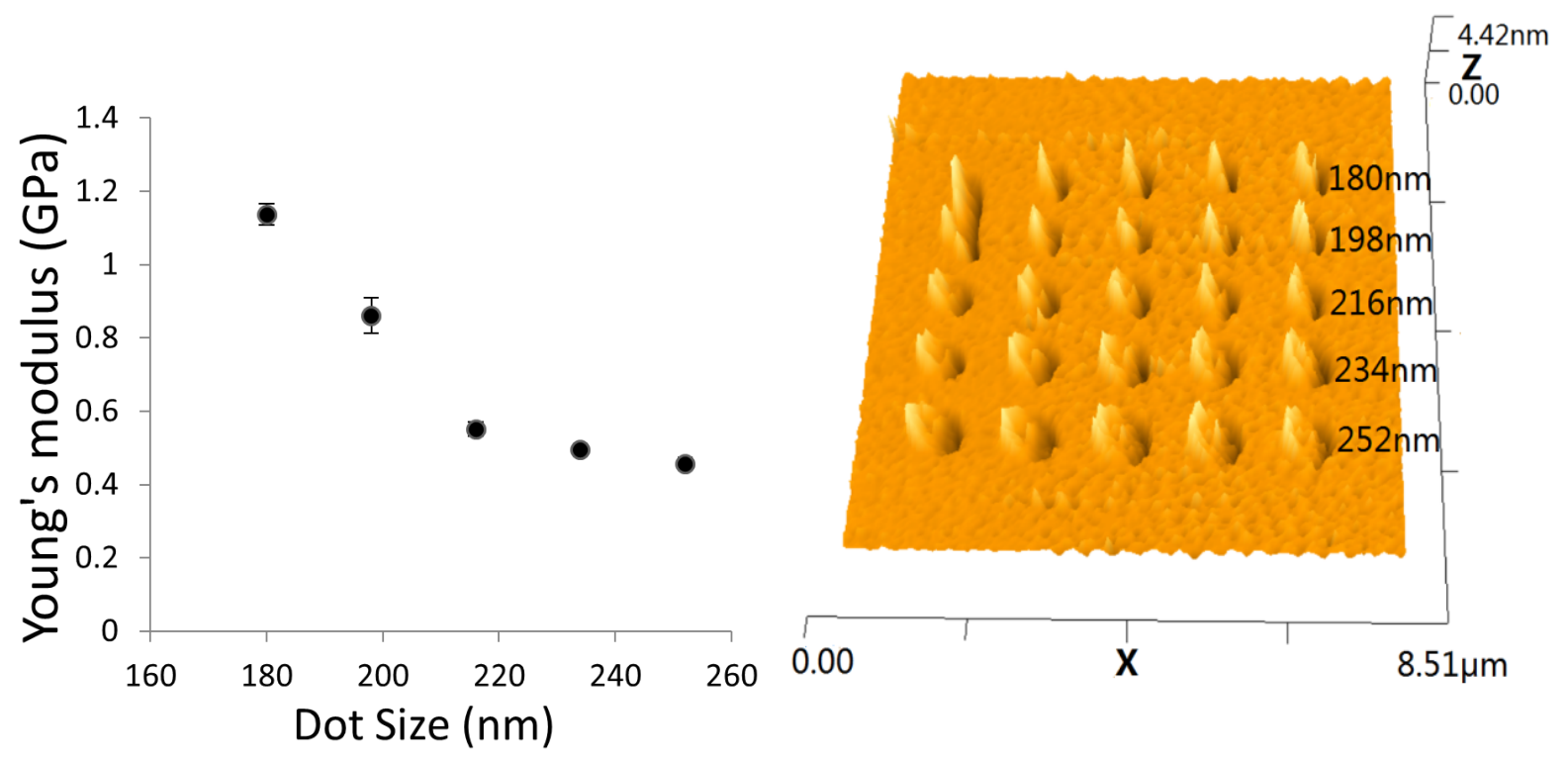

Figure 10. Stiffness of streptavidin functionalized pores of varying sizes in the range of $180-250 \mathrm{~nm}$. Each point is the averaged elastic moduli of 80 measurements in dry state. Pore 
diameters are labeled on the AFM topographical image.

\section{CONCLUSION}

We have functionalized the nanopores of polymer thin films with proteins to investigate surface elastic properties. Pores of varying sizes were fabricated in PS and PMMA films and were functionalized with proteins. FTIR, nanoindentation and contact angle measurements confirmed that proteins were chemically tethered into cylindrical and striped pores. Indentation experiments conducted on these heterogeneous polymer-protein functionalized surfaces revealed that streptavidin confined in nanopores was found to be stiffer than the one within sub-micron pores. Activity results showed that the immobilized enzymes in nanopores remained active. These results suggest that stiffness of proteins changed with the hydrophobic polymer at confining medium and this effect may lead to a decrease in protein activity when compared to the free protein in solution. The elasticity of polymer-protein tethered surfaces presents novel findings as most studies investigate the topography and protein adhesion but not the mechanical properties. Direct immobilization of proteins into the porous copolymer templates offers wide range of applications from biosensing to biomedical devices. Further studies on these heterogeneous polymer-protein functionalized surfaces will focus on the relations between protein stiffness, polymer type, protein size and their bioactivity.

\section{ASSOCIATED CONTENT}

\section{Supporting Information}

Variation of sub-micron size with voltage; fluorescence microscopy images of unmodified 
and protein modified porous films after washing with fluorescent-labeled streptavidin; AFM topography images of lysozyme modified cylindrical and striped nanopores; FTIR spectra of open nanopores and protein washed surfaces. This material is available free of charge via the Internet at http://pubs.acs.org.

\section{AUTHOR INFORMATION}

\section{Corresponding Author}

*Telephone: (201) 216-5060. Fax: (201) 216-8306. E-mail: pakcora@stevens.edu

\section{Notes}

The authors declare no competing financial interest.

\section{ACKNOWLEDGMENTS}

We acknowledge the Multiscale Imaging Lab (LMSI) and the MicroDevice Lab (MDL) at Stevens Institute of Technology. We thank Dr. Hongjun Wang for the use of microplate reader. We also thank Dr. Dmytro Nykypanchuk for his help with AFM at CFN. Research carried out in part at the Center for Functional Nanomaterials (CFN), Brookhaven National Laboratory, which is supported by the U.S. Department of Energy, Office of Basic Energy Sciences, under Contract No. DE-SC0012704.

\section{REFERENCES}

1. Holmes, P.; Currie, E.; Thies, J.; Van der Mei, H.; Busscher, H.; Norde, W., Surface modified nanoparticles as a new, versatile, and mechanically robust nonadhesive coating: Suppression of protein adsorption and bacterial adhesion. Journal of Biomedical Materials Research Part A 2009, 91 (3), 824-833.

2. Kao, W.; Hubbell, J.; Anderson, J., Protein-mediated macrophage adhesion and activation on biomaterials: a model for modulating cell behavior. Journal of materials science: materials in medicine 1999, 10 (10-11), 601-605.

3. Collier, T. O.; Thomas, C. H.; Anderson, J. M.; Healy, K. E., Surface chemistry control 
of monocyte and macrophage adhesion, morphology, and fusion. Journal of biomedical materials research 2000, 49 (1), 141-145.

4. Phizicky, E.; Bastiaens, P. I.; Zhu, H.; Snyder, M.; Fields, S., Protein analysis on a proteomic scale. Nature 2003, 422 (6928), 208-215.

5. Secundo, F., Conformational changes of enzymes upon immobilisation. Chemical Society Reviews 2013, 42 (15), 6250-6261.

6. Talbert, J. N.; Goddard, J. M., Enzymes on material surfaces. Colloids and Surfaces B: Biointerfaces 2012, 93, 8-19.

7. Hong, R.; Emrick, T.; Rotello, V. M., Monolayer-controlled substrate selectivity using noncovalent enzyme-nanoparticle conjugates. Journal of the American Chemical Society 2004, 126 (42), 13572-13573.

8. de la Rica, R.; Aili, D.; Stevens, M. M., Enzyme-responsive nanoparticles for drug release and diagnostics. Advanced drug delivery reviews 2012, 64 (11), 967-978.

9. Xie, Y.; Zhou, J.; Jiang, S., Parallel tempering Monte Carlo simulations of lysozyme orientation on charged surfaces. The Journal of chemical physics 2010, 132 (6), 065101.

10. Malinin, A.; Rakhnyanskaya, A.; Bacheva, A.; Yaroslavov, A., Activity of an enzyme immobilized on polyelectrolyte multilayers. Polymer Science Series A 2011, 53 (1), 52-56.

11. Wei, Q.; Becherer, T.; Angioletti - Uberti, S.; Dzubiella, J.; Wischke, C.; Neffe, A. T.; Lendlein, A.; Ballauff, M.; Haag, R., Protein interactions with polymer coatings and biomaterials. Angewandte Chemie International Edition 2014, 53 (31), 8004-8031.

12. Matthews, B. W., Hydrophobic interactions in proteins. eLS 2001.

13. You, C.-C.; De, M.; Han, G.; Rotello, V. M., Tunable inhibition and denaturation of a -chymotrypsin with amino acid-functionalized gold nanoparticles. Journal of the American Chemical Society 2005, 127 (37), 12873-12881.

14. Roach, P.; Farrar, D.; Perry, C. C., Interpretation of protein adsorption: surface-induced conformational changes. Journal of the American Chemical Society 2005, 127 (22), 8168-8173.

15. Denis, F. A.; Hanarp, P.; Sutherland, D. S.; Gold, J.; Mustin, C.; Rouxhet, P. G.; Dufrêne, Y. F., Protein adsorption on model surfaces with controlled nanotopography and chemistry. Langmuir 2002, 18 (3), 819-828.

16. Rechendorff, K.; Hovgaard, M. B.; Foss, M.; Zhdanov, V.; Besenbacher, F., Enhancement of protein adsorption induced by surface roughness. Langmuir 2006, 22 (26), 10885-10888.

17. Jonkheijm, P.; Weinrich, D.; Schröder, H.; Niemeyer, C. M.; Waldmann, H., Chemical strategies for generating protein biochips. Angewandte Chemie International Edition 2008, 47 (50), 9618-9647.

18. Hernandez, K.; Fernandez-Lafuente, R., Control of protein immobilization: coupling immobilization and site-directed mutagenesis to improve biocatalyst or biosensor performance. Enzyme and microbial technology 2011, 48 (2), 107-122.

19. Mateo, C.; Palomo, J. M.; Fernandez-Lorente, G.; Guisan, J. M.; Fernandez-Lafuente, R., Improvement of enzyme activity, stability and selectivity via immobilization techniques. Enzyme and Microbial Technology 2007, 40 (6), 1451-1463.

20. Sung, D.; Park, S.; Jon, S., Facile immobilization of biomolecules onto various surfaces using epoxide-containing antibiofouling polymers. Langmuir 2012, 28 (9), 4507-4514. 
21. Lei, H.; Wang, M.; Tang, Z.; Luan, Y.; Liu, W.; Song, B.; Chen, H., Control of Lysozyme Adsorption by $\mathrm{pH}$ on Surfaces Modified with Polyampholyte Brushes. Langmuir 2014, 30 (2), 501-508.

22. Viswanath, S.; Wang, J.; Bachas, L.; Butterfield, D.; Bhattacharyya, D., Site-directed and random immobilization of subtilisin on functionalized membranes: activity determination in aqueous and organic media. Biotechnology and bioengineering 1998, 60 (5), 608-616.

23. Weber, P. C.; Ohlendorf, D.; Wendoloski, J.; Salemme, F., Structural origins of high-affinity biotin binding to streptavidin. Science 1989, 243 (4887), 85-88.

24. Wacker, R.; Schröder, H.; Niemeyer, C. M., Performance of antibody microarrays fabricated by either DNA-directed immobilization, direct spotting, or streptavidin-biotin attachment: a comparative study. Analytical biochemistry 2004, 330 (2), 281-287.

25. Wacker, R.; Niemeyer, C. M., DDI - $\mu$ FIA - A Readily Configurable Microarray Fluorescence Immunoassay Based on DNA - Directed Immobilization of Proteins. ChemBioChem 2004, 5 (4), 453-459.

26. Erol, M.; Du, H.; Sukhishvili, S., Control of specific attachment of proteins by adsorption of polymer layers. Langmuir 2006, 22 (26), 11329-11336.

27. Stuart, M. A. C.; Huck, W. T.; Genzer, J.; Müller, M.; Ober, C.; Stamm, M.; Sukhorukov, G. B.; Szleifer, I.; Tsukruk, V. V.; Urban, M., Emerging applications of stimuli-responsive polymer materials. Nature materials 2010, 9 (2), 101-113.

28. Nederberg, F.; Watanabe, J.; Ishihara, K.; Hilborn, J.; Bowden, T., Biocompatible and biodegradable phosphorylcholine ionomers with reduced protein adsorption and cell adhesion. Journal of Biomaterials Science, Polymer Edition 2006, 17 (6), 605-614.

29. Ma, H.; Li, D.; Sheng, X.; Zhao, B.; Chilkoti, A., Protein-resistant polymer coatings on silicon oxide by surface-initiated atom transfer radical polymerization. Langmuir 2006, 22 (8), 3751-3756.

30. Hoy, O.; Zdyrko, B.; Lupitskyy, R.; Sheparovych, R.; Aulich, D.; Wang, J.; Bittrich, E.; Eichhorn, K. J.; Uhlmann, P.; Hinrichs, K., Synthetic hydrophilic materials with tunable strength and a range of hydrophobic interactions. Advanced Functional Materials 2010, 20 (14), 2240-2247.

31. Katira, P.; Agarwal, A.; Hess, H., A random sequential adsorption model for protein adsorption to surfaces functionalized with poly (ethylene oxide). Advanced Materials 2009, 21 (16), 1599-1604.

32. Michel, R.; Pasche, S.; Textor, M.; Castner, D. G., Influence of PEG architecture on protein adsorption and conformation. Langmuir 2005, 21 (26), 12327-12332.

33. Gon, S.; Bendersky, M.; Ross, J. L.; Santore, M. M., Manipulating protein adsorption using a patchy protein-resistant brush. Langmuir 2010, 26 (14), 12147-12154.

34. Chen, S.; Zheng, J.; Li, L.; Jiang, S., Strong resistance of phosphorylcholine self-assembled monolayers to protein adsorption: insights into nonfouling properties of zwitterionic materials. Journal of the American Chemical Society 2005, 127 (41), 14473-14478.

35. Keller, K.; Amirian, A.; Akcora, P., Elastic Properties of a Protein-Polymer-Grafted Surface. Langmuir 2012, 28 (8), 3807-3813.

36. Carlsson, N.; Gustafsson, H.; Thörn, C.; Olsson, L.; Holmberg, K.; Åkerman, B., Enzymes immobilized in mesoporous silica: A physical-chemical perspective. Advances in 
colloid and interface science 2014, 205, 339-360.

37. Kunkel, J.; Asuri, P., Function, Structure, and Stability of Enzymes Confined in Agarose Gels. PloS one 2014, 9 (1), e86785.

38. Radhakrishna, M.; Grimaldi, J.; Belfort, G.; Kumar, S. K., Stability of proteins inside a hydrophobic cavity. Langmuir 2013, 29 (28), 8922-8928.

39. Bolis, D.; Politou, A. S.; Kelly, G.; Pastore, A.; Temussi, P. A., Protein stability in nanocages: a novel approach for influencing protein stability by molecular confinement. Journal of molecular biology 2004, 336 (1), 203-212.

40. Sang, L.-C.; Coppens, M.-O., Effects of surface curvature and surface chemistry on the structure and activity of proteins adsorbed in nanopores. Physical Chemistry Chemical Physics 2011, 13 (14), 6689-6698.

41. Deere, J.; Magner, E.; Wall, J. G.; Hodnett, B. K., Mechanistic and structural features of protein adsorption onto mesoporous silicates. The Journal of Physical Chemistry B 2002, 106 (29), 7340-7347.

42. Schlipf, D. M.; Rankin, S. E.; Knutson, B. L., Pore-Size Dependent Protein Adsorption and Protection from Proteolytic Hydrolysis in Tailored Mesoporous Silica Particles. ACS applied materials \& interfaces 2013, 5 (20), 10111-10117.

43. Pradier, C. M.; Salmain, M.; Liu, Z.; Methivier, C., Comparison of different procedures of biotin immobilization on gold for the molecular recognition of avidin: an FT - IRRAS study. Surface and interface analysis 2002, 34 (1), 67-71.

44. Hoyle, C. E.; Bowman, C. N., Thiol-ene click chemistry. Angewandte Chemie International Edition 2010, 49 (9), 1540-1573.

45. Sugimura, H.; Nakagiri, N., Scanning probe anodization: nanolithography using thin films of anodically oxidizable materials as resists. Journal of Vacuum Science \& Technology A 1996, 14 (3), 1223-1227.

46. Vinckier, A.; Semenza, G., Measuring elasticity of biological materials by atomic force microscopy. Febs Letters 1998, 430 (1), 12-16.

47. Kuznetsova, T. G.; Starodubtseva, M. N.; Yegorenkov, N. I.; Chizhik, S. A.; Zhdanov, R. I., Atomic force microscopy probing of cell elasticity. Micron 2007, 38 (8), 824-833.

48. Kurland, N. E.; Drira, Z.; Yadavalli, V. K., Measurement of nanomechanical properties of biomolecules using atomic force microscopy. Micron 2012, 43 (2), 116-128.

49. Cappella, B.; Dietler, G., Force-distance curves by atomic force microscopy. Surface science reports 1999, 34 (1), 1-104.

50. Haga, H.; Sasaki, S.; Kawabata, K.; Ito, E.; Ushiki, T.; Sambongi, T., Elasticity mapping of living fibroblasts by AFM and immunofluorescence observation of the cytoskeleton. Ultramicroscopy 2000, 82 (1), 253-258.

51. Espinosa, M. G.; Gardner, W. S.; Bennett, L.; Sather, B. A.; Yanagisawa, H.; Wagenseil, J. E., The Effects of Elastic Fiber Protein Insufficiency and Treatment on the Modulus of Arterial Smooth Muscle Cells. Journal of biomechanical engineering 2014, 136 (2), 021030.

52. Radmacher, M.; Fritz, M.; Cleveland, J. P.; Walters, D. A.; Hansma, P. K., Imaging adhesion forces and elasticity of lysozyme adsorbed on mica with the atomic force microscope. Langmuir 1994, 10 (10), 3809-3814.

53. Chizhik, S.; Huang, Z.; Gorbunov, V.; Myshkin, N.; Tsukruk, V., Micromechanical properties of elastic polymeric materials as probed by scanning force microscopy. Langmuir 
1998, 14 (10), 2606-2609.

54. Carpick, R. W.; Ogletree, D. F.; Salmeron, M., A general equation for fitting contact area and friction vs load measurements. Journal of Colloid and Interface Science 1999, 211 (2), 395-400.

55. J Roa, J.; Oncins, G.; Diaz, J.; Sanz, F.; Segarra, M., Calculation of Young's Modulus Value by Means of AFM. Recent patents on nanotechnology 2011, 5 (1), 27-36.

56. Zhang, L.; Wang, L.; Kao, Y.-T.; Qiu, W.; Yang, Y.; Okobiah, O.; Zhong, D., Mapping hydration dynamics around a protein surface. Proceedings of the National Academy of Sciences 2007, 104 (47), 18461-18466.

57. Tompa, K.; Bokor, M.; Verebélyi, T.; Tompa, P., Water rotation barriers on protein molecular surfaces. Chemical Physics 2015, 448, 15-25.

58. Li, B.; Alonso, D. O.; Bennion, B. J.; Daggett, V., Hydrophobic hydration is an important source of elasticity in elastin-based biopolymers. Journal of the American Chemical Society 2001, 123 (48), 11991-11998.

59. Speziale, S.; Jiang, F.; Caylor, C. L.; Kriminski, S.; Zha, C. S.; Thorne, R. E.; Duffy, T. S., Sound Velocity and Elasticity of Tetragonal Lysozyme Crystals by Brillouin Spectroscopy. Biophysical Journal 2003, 85 (5), 3202-3213.

60. Roach, P.; Farrar, D.; Perry, C. C., Surface tailoring for controlled protein adsorption: effect of topography at the nanometer scale and chemistry. Journal of the American Chemical Society 2006, 128 (12), 3939-3945.

61. Li, X.; Wang, M.; Wang, L.; Shi, X.; Xu, Y.; Song, B.; Chen, H., Block copolymer modified surfaces for conjugation of biomacromolecules with control of quantity and activity. Langmuir 2013, 29 (4), 1122-1128. 


\title{
TABLE OF CONTENTS
}

\section{Elastic Properties of Protein Functionalized Nanoporous Polymer Films}

\author{
Haoyu Wang ${ }^{1}$, Charles T. Black ${ }^{2}$ and Pinar Akcora ${ }^{1}$ \\ ${ }^{1}$ Department of Chemical Engineering and Materials Science \\ Stevens Institute of Technology, 1 Castle Point on Hudson
}

Hoboken, New Jersey 07030, USA

${ }^{2}$ Center for Functional Nanomaterials, Brookhaven National Laboratory

Upton, New York 11973, USA

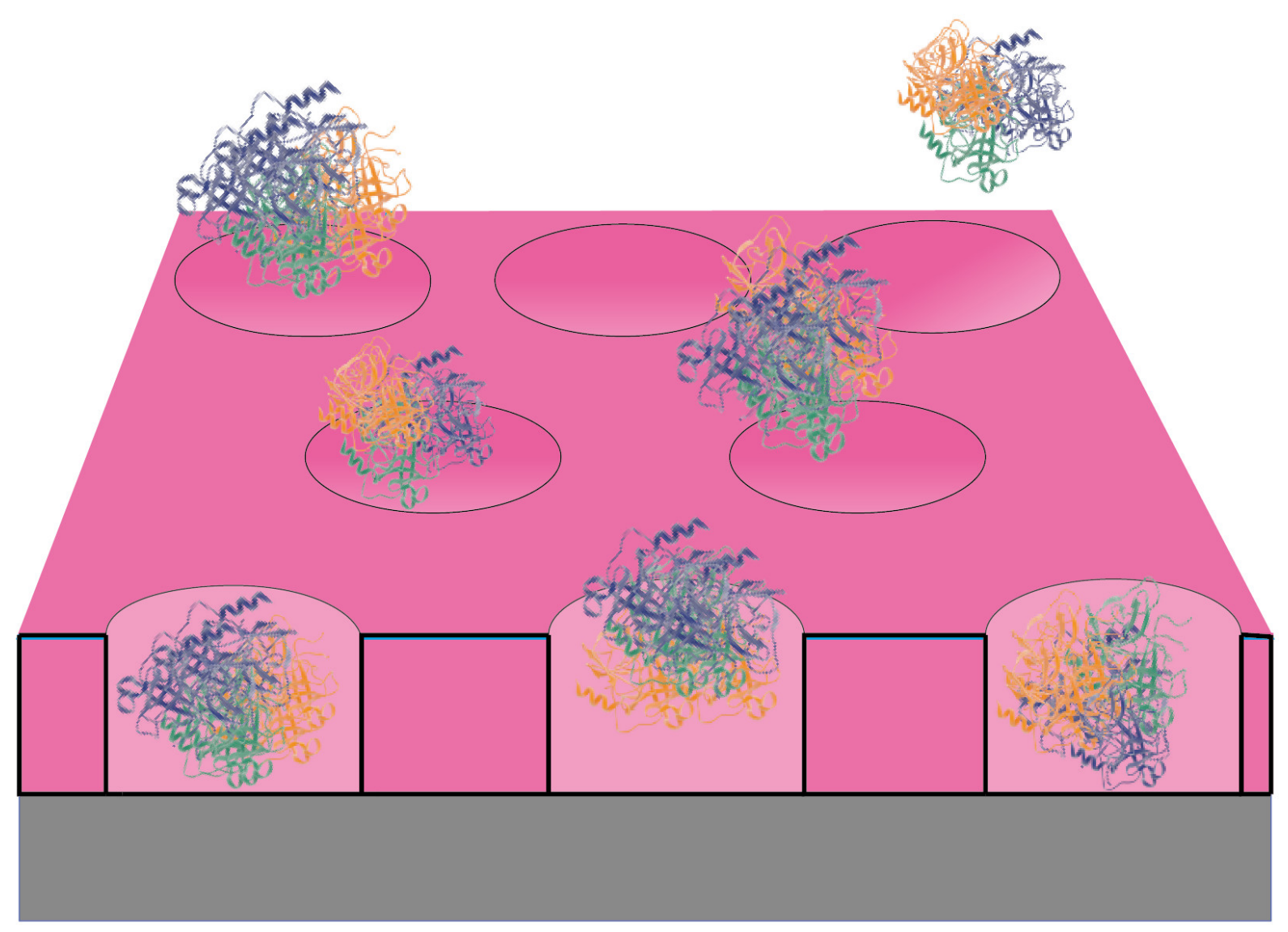

